\title{
MINERAL INSULATORS FOR KOMPTON DETECTORS OF NEUTRONS WITH A METAL HAFNIUM EMITTER
}

\author{
E.A. Bohdan, L.A. Pirozhenko, R.V. Azhazha, S.V. Khudyakov, A.A. Vierovkin, A.V. Rybka, \\ V.E. Kutny, K.V. Kovtun, S.A. Sokolov, A.L. Ulybkin, A.O. Pudov \\ National Science Center "Kharkov Institute of Physics and Technology”, Kharkiv, Ukraine \\ E-mail: janegm61@gmail.com
}

One of the priority tasks of nuclear power industry is to increase the reliability and safety of nuclear power plants. In this regard, traditional detectors for measuring the neutron flux in the reactor core are being improved and new ones are developed. This work is dedicated to one of the tasks of creating a compton self-powered neutron detector, namely, the formation of an insulator of magnesium oxide on an emitter of metallic hafnium. The effect of three types of magnesium oxide of different purity and structural state, as well as annealing temperature on the electrical resistance of the insulator between the collector and the emitter of the detector, is studied. The detector prototypes were manufactured by filling with magnesium oxidepowders or by applying liquid-phase mixturesthereof.

\section{INTRODUCTION}

For more efficient operation, increased reliability and safety of nuclear reactors, it is necessary to improve existing systems for monitoring and controlling the core. For this purpose, self-powered neutron detectors (SPNDs) used in in-reactor monitoring systems are developed and investigated. The advantages of SPNDs are the design simplicity, the small size, the absence of a power supply, the stability with respect to temperature and pressure. Moreover, the Compton SPNDs with an emitter of metallic hafnium would be practically inertialess and have a low rate of burnout of the material of the emitter. Due to the instantaneous response of Compton SPNDs to a change in the neutron flux in the reactor core, it is possible to increase the burn up rate of nuclear fuel, to determine the place and the starttime of the crisis boiling of the coolant on the surface of the fuel elements [1]. An SPND with a hafnium emitter is also promising in automatic control systems, control and protection of low-power modular reactors, where increased performance requirements are imposed [1, 3].

Since SPND is installed directly in the active zone of a nuclear reactor, a special approach to the selection of materials and the development of technological processes for their manufacture is necessary. One of the main elements of SPND is its insulator. It should have high electrical resistance, high radiation resistance and maintain its characteristics in wide ranges of temperature and neutron fluence.

The goal of this work is to select, manufacture and study an insulator for Compton SPND with an emitter of metallic hafnium, which would satisfy the requirements for in-core detectors.

\section{MATERIALS AND METHODS OF INVESTIGATION}

To study the properties of the insulator, mock detectors were made, a schematic view of which is shown in Fig. 1.

The electrical resistance was measured in the automatic mode by using a Keithley 6487 picoammeter and the ExceLINX software.

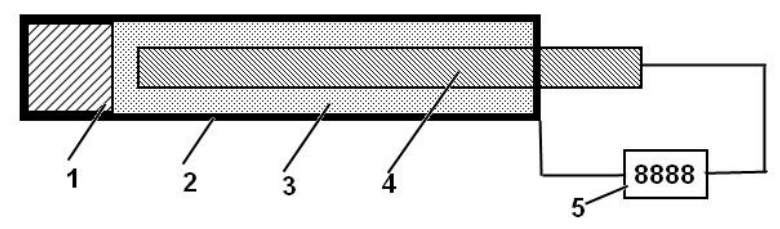

Fig. 1. The schematic of the SPND:

1-plug; 2 -collector; 3 -insulator; 4-emitter; 5 - picoammeter

To study the surface condition of the insulator, we used a Leica Z6 APO optical microscope with a ring segmented LED illuminator in combination with a Leica DFC digital camera.

For the emitter, a hafnium wire of the HFE-1 grade with a diameter of $1.5 \mathrm{~mm}$ manufactured using the original technology [4] developed in ISSPMT (Institute of Solid State Physics, Materials Science and Technologies, NAS of Ukraine) was used. The chemical composition of the material meets the requirements of TUU 143 12708.183-95. The final preparation of the hafnium emitter was essentially the chemical polishing of the surface and subsequent vacuum annealing for one hour at a temperature of $850{ }^{\circ} \mathrm{C}$. The blank of the collector was a tube of stainless steel X18H10T with a diameter of $5 \mathrm{~mm}$ and a wall thickness of $0.25 \mathrm{~mm}$. Before using the tube, its inner surface was polished, first by mechanical and then electrochemical methods, to obtain a mirror shine.

Magnesium oxides of different purity levels were taken as materials for the manufacture of various samples of insulators. The appearance of the starting powders is shown in Fig. 2.

Fig. 2,a shows magnesium oxide of qualification "pure" with a mass fraction of the main substance of $>97.0 \%$, which is a light loose powder of white color. The oxide of the same purity class, but preliminarily heat - treated at $1300{ }^{\circ} \mathrm{C}$ in air, is shown in Fig. 2, b. After annealing at this temperature, all powder particles acquire a spherical shape, which is the most energetically favorable. Unlike the previous powder, this one is less hygroscopic. 


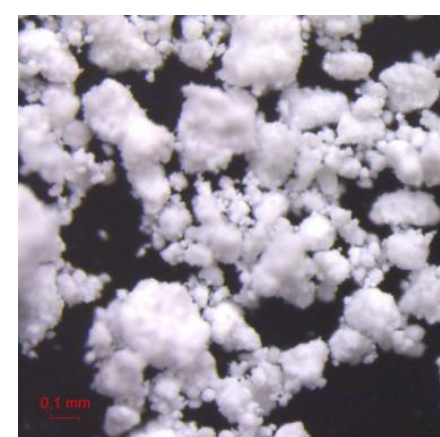

$a$
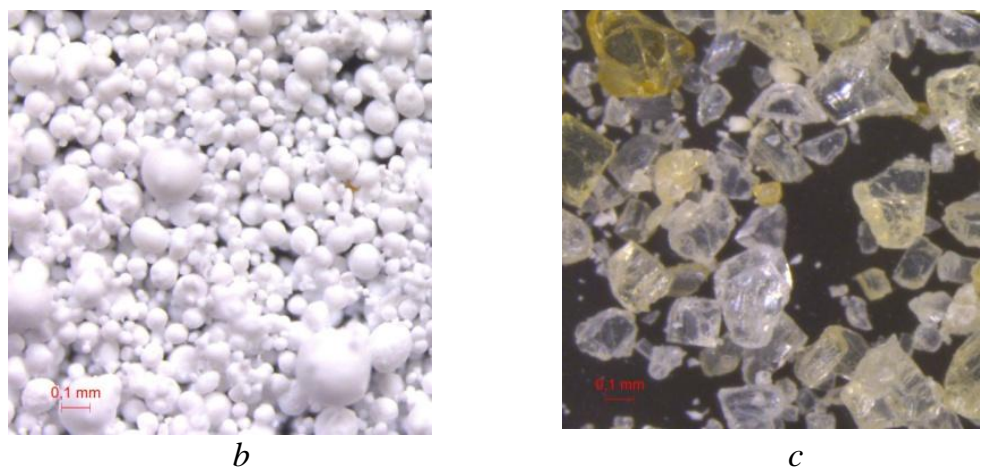

$c$

Fig. 2. Magnesium oxide: GOST 4526-75 (pure) (a); GOST 4526-75 (pure) heated at $1300{ }^{\circ} \mathrm{C}$ in air (b); periclase (c)

One more material chosen for studying was periclase (see Fig. 2,c), (periclase is magnesium oxide annealed at a temperature of $>1600{ }^{\circ} \mathrm{C}$ ). This magnesium oxide is in the form of transparent crystals of various shapes and sizes, crystals of different colors are observed, which indicates the presence of impurities in the composition. The $\mathrm{MgO}$ content in this powder, based on the certificate, is $>96 \%$. Periclase is used as dielectric powder filling in high-temperature heating elements, which operate up to $1000^{\circ} \mathrm{C}$.

The insulators were made in two ways: by filling the collector-emitter gap with the annealed magnesium oxide, and by applying a liquid-phase magnesia mixture directly onto the surface of the emitter.

The filling method consisted of pressing a preannealed at a temperature of $900{ }^{\circ} \mathrm{C}$ magnesium oxide powder. The standard technology for manufacturing cables with heat-resistant mineral insulation was taken as the basis [5]. The prepared powder was poured into the gap between the collector and the emitter. A vibrational stage was used to evenly distribute magnesium oxide powder, and a punch was used for compaction, which simultaneously centered the emitter relative to the walls of the collector. Then, the detector blank was drawn with periodic annealing to obtain the specified diameter of the detector. An insulator made in this way has the form of a densely pressed powder.

The second method of obtaining the insulator is to apply a liquid-phase mixture-suspension directly to the surface of the emitter [6]; after the mixture has solidified, the emitter with insulation is pulled into the collector. The suspension consisted of a saturated aqueous solution of crystalline hydrate of magnesium salt and dry annealed powder of magnesium oxide of various purity levels.

\section{RESULTS AND DISCUSSION}

When mixing the crystalline hydrate of a magnesium salt and a dry annealed powder of magnesium oxide, several parallel chemical reactions take place:

$$
\begin{gathered}
\mathrm{MgO}+\mathrm{H}_{2} \mathrm{O} \rightarrow \mathrm{Mg}(\mathrm{OH})_{2}, \\
\mathrm{MgO}+\mathrm{Mg}\left(\mathrm{NO}_{3}\right)_{2} \stackrel{1}{\rightarrow} \\
\stackrel{1}{\rightarrow}\left\{\begin{array}{l}
3 \mathrm{MgO} \cdot \mathrm{Mg}\left(\mathrm{NO}_{3}\right)_{2} \cdot 6 \mathrm{H}_{2} \mathrm{O} \\
5 \mathrm{MgO} \cdot \mathrm{Mg}\left(\mathrm{NO}_{3}\right)_{2} \cdot 11 \mathrm{H}_{2} \mathrm{O}
\end{array}\right\} \stackrel{2}{\rightarrow} \\
\stackrel{2}{\rightarrow} \mathrm{NO}_{3}-\mathrm{Mg}-\mathrm{O}-(\mathrm{Mg}-\mathrm{O}) n-\mathrm{Mg}-\mathrm{NO}_{3} .
\end{gathered}
$$

The first reaction accounts for a very small percentage of transformations, since there is little free water in the solution; this reaction proceeds only on the surfaces of $\mathrm{MgO}$ crystals. The transformations according to the second scheme account for a large proportion of the initial components of the suspension. Metastable pentaoxynitrate occurs as the first reaction product in the region of high $\mathrm{MgO}$ concentrations. As magnesium oxide is consumed, the reaction of recrystallization of metastable pentaoxynitrate into stable magnesium trioxynitrate is activated. Further transformations and hardening of the suspension lead to the formation of the final reaction product - long-chain magnesian cement $(\mathrm{Mg}-\mathrm{O}) \mathrm{n}$ (the second part of the scheme) directly on the surface of the emitter. To obtain an insulator of the required thickness, three layers of cement were applied. Each subsequent layer was applied after complete drying of the previous one.

As a result of the hardening of the suspension, magnesia cement is formed, which includes magnesium hydroxide, magnesia nitrate polymer and water. Fig. 3 shows photos of the cross sections of the detectors. Fig. $\mathbf{3}$, a shows the cement deposited on a hafnium emitter and drawn into a steel collector. Three layers of glassy cement are clearly visible. At this stage, cement is not yet an insulator, since its resistance is not high due to the excess of moisture and nitrogen compounds. To remove these undesirable components and spliced layers, the blank was subjected to several annealingdrawing cycles. As a result of this treatment, the following chemical reactions occur in the insulator:

$\mathrm{NO}_{3}-\mathrm{Mg}-\mathrm{O}-(\mathrm{Mg}-\mathrm{O}) \mathrm{n}-\mathrm{Mg}-\mathrm{NO}_{3}$
$\mathrm{Mg}(\mathrm{OH})_{2}$

$\stackrel{T}{\rightarrow} \mathrm{MgO}+\mathrm{NO}_{2} \uparrow+\mathrm{H}_{2} \mathrm{O} \uparrow$.

After the first annealing-drawing cycle, cement has the form shown in Fig. 3,b. At this stage of the manufacture of the insulator, partial removal of water and nitrogen compounds occurs, and the thermal decomposition of the $(\mathrm{Mg}-\mathrm{O}) \mathrm{n}$ chain begins with theformation of crystalline and amorphous $\mathrm{MgO}$, and the first and second layers of cement begin merge with each other. Fig. 3,c shows the final state of the insulator after removal of the volatile reaction products and the conversion of magnesia cement to magnesium oxide. 


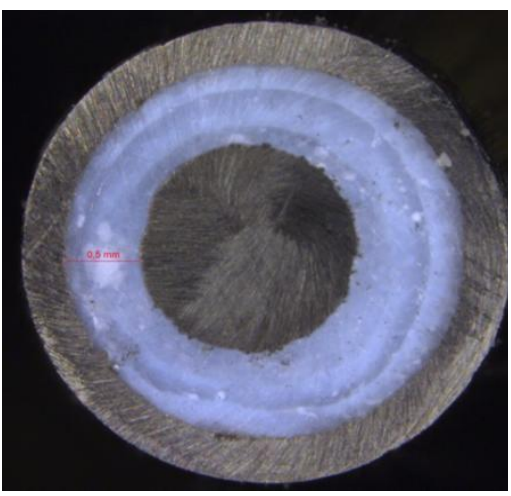

$a$

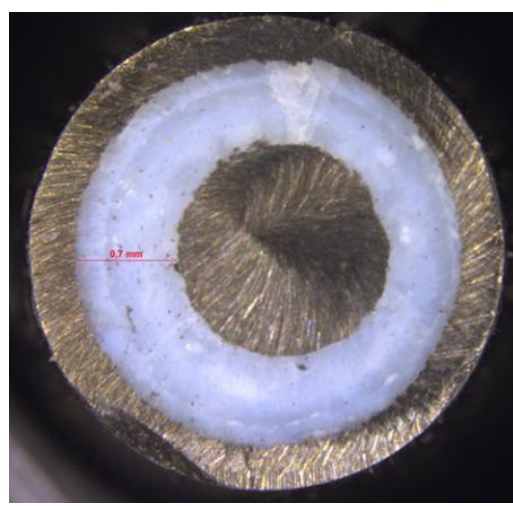

$b$

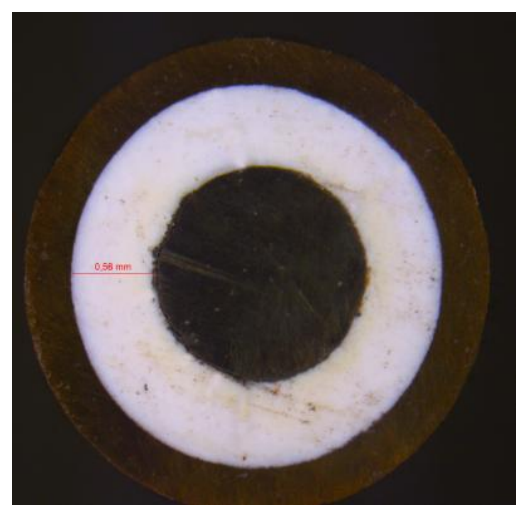

$c$

Fig. 3. Photos of insulators between the collector and the emitter, obtained by applying a liquid-phase suspension

To establish the effect of the final annealing of the detector on the electrical resistance, a number of samples were made by both methods of producing an insulator based on the above magnesium oxides. After a complete manufacturing cycle, all samples were subjected to anneals at temperatures from 100 to $800{ }^{\circ} \mathrm{C}$ in increments of $100{ }^{\circ} \mathrm{C}$, for one hour at each temperature, in a muffle furnace, and their resistance was measured.

Fig. 4 and 5 show the dependences of the electrical resistance of the insulator on the annealing temperature. It can be seen from the graph that the resistance of all samples increases when the anneal temperature reaches $300{ }^{\circ} \mathrm{C}$, which is explained by the removal of water from the surface of the powder for the insulator obtained by the powder filling method and by the continuation of chemical reactions according to scheme

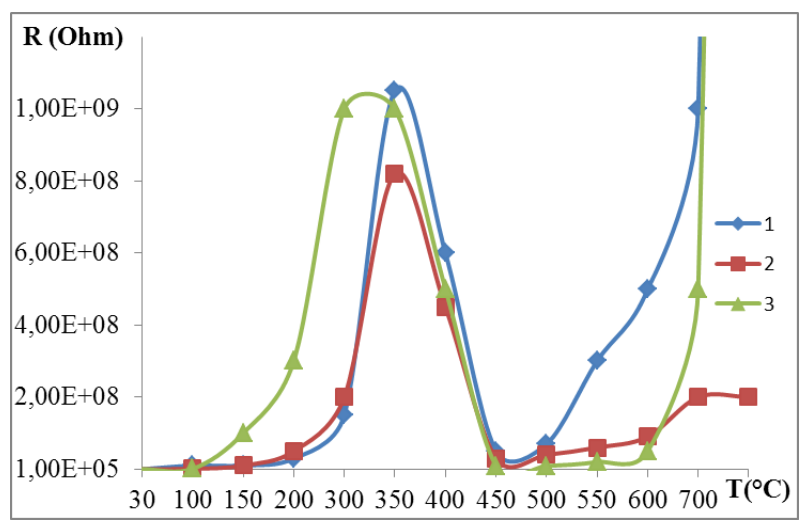

Fig. 4. The dependence of the electrical resistance after annealing at different temperatures of the insulators obtained by applying a suspension to the emitter: 1 - MgO GOST 4526-75; 2 - MgO GOST 4526-75 previously annealed at $1300{ }^{\circ} \mathrm{C} ; 3$ - periclase

In the case of the insulators obtained from the magnesia cement, annealing at $400{ }^{\circ} \mathrm{C}$, apparently, contributes to the maximum thermal decomposition of amorphous and crystalline magnesium hydroxide into amorphous and crystalline oxide, respectively [7], which is also accompanied by the evaporation of water. On the graph (see Fig. 4), this is characterized by a drop in the electrical resistance. With a further increase in the annealing temperature of such an insulator, the magnesia cement is completely destroyed with the formation of magnesium oxide. On the graph, this
(3), for the insulator obtained by the second method. At $400{ }^{\circ} \mathrm{C}$, a sharp drop in the resistance of the insulators is observed regardless of the method of their production, the nature of this phenomenon is different for each of the production methods. Apparently, in insulators manufactured by the powder filling method (see Fig. 5), the powder is densified in the gap between the emitter and the collector, which leads to its deformation, grinding, and activation of the surface of $\mathrm{MgO}$ particles, and therefore the hygroscopicity of the powder increases. During theanneal at $400{ }^{\circ} \mathrm{C}$, the occluded water is removed from the surfaces of the particles. And since the water cannot evaporate all at once, and part of it remains at the grain boundaries, the conductivity of the magnesium oxide powder increases. This is characteristic of all three selected powders.

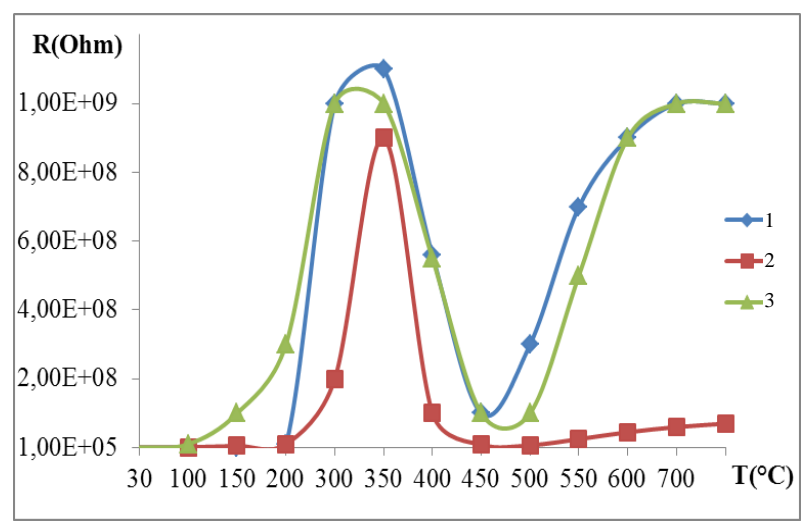

Fig. 5.The dependence of electrical resistance after annealing at different temperatures of the insulator obtained by the powder filling method:

1 - MgO GOST 4526-75; 2 - MgO GOST 4526-75 previously annealed at $1300{ }^{\circ} \mathrm{C} ; 3$ - periclase

process is characterized by an increase in resistance. When annealing at $600 \ldots 700^{\circ} \mathrm{C}$, coalescence of magnesium oxide crystals occurs, and, accordingly, their number decreases. As some current may flow along the boundaries of the crystals, a decrease in their number would lead to an increase in electrical resistance. After annealing at $700{ }^{\circ} \mathrm{C}$ of the samples obtained from magnesium oxide GOST 4526-75, the resistance value was $1 \cdot 10^{10} \Omega$ (see Fig. 4, curve 1, 3).

Unfortunately, the same effect of resistance growth was not observedto the same degree for the insulators 
obtained by the powder filling and for the samples obtained by applying a liquid-phase suspension with the powder GOST $4526-75$, initially annealed at $1300^{\circ} \mathrm{C}$ (see Fig. 5, curve 2). Perhaps such crystals are not as capable of merging together.

\section{CONCLUSIONS}

For the manufacture of the insulators for SPND with an emitter of hafnium metal, we studied the electrophysical characteristics of $\mathrm{MgO}$ obtained from three types of initial magnesia compositions in two ways: by applying a suspension and by powder filling. It is shown that the insulators obtained from the powder of $\mathrm{MgO}$ GOST 4526-75 initially annealed at $1300{ }^{\circ} \mathrm{C}$ do not reach a sufficiently high resistance. Therefore, powders without preliminary annealing and periclase were selected for further studies. The insulators made of these powders have the best electrical resistance. The application of a liquid-phase suspension to the emitter ensures uniformity of the composition of the insulation along the entire length of the detector, a higher and more stable electrical resistance, as well as a more accurate alignment of the emitter relative to the collector. The powder filling method is simpler in manufacturing, does not require additional operations and chemicals, but the final electrical resistance of such insulator is typically lower.

\section{REFERENCES}

1. B.A. Shilyaev et al. Compton detector of neutrons for the energy yield control in the active zone of WWER // Problems of Atomic Science and Technology. 2017, N 2(108), p. 75-82.

2. А.Л. Улыбкин, Б.А. Шиляев, К.В. Ковтун, А.В. Рыбка, В.Е. Кутний, А.О. Пудов, А.А. Васильев. Чистый гафний - материал важнейших элементов конструкции ядерных реакторов // Maтериаль докладов 4-й конференции «Высокочистые материаль: получение, применения, свойства», 2017.

3. A.L. Ulybkin et al. Compton-Emissive Hafnium Detector of Neutrons for In-Core Monitoring // Nucl. Phys. At. Energy, Section: Atomic Energy. 2018, v. 19(3), p. $237-$ 243.

4. Р.В. Ажажа, К.В. Ковтун, М.П. Старолат, JI.Н. Чепурная. Исследование структуры и свойств проволоки из гафния // Металлофизика и новейшие технологии. 2013, т. 35, №5, с. 677-682.

5. В.Ф. Сучков, В.И. Светлова, Э.Э. Финкель. Жаростойкие кабеля с магнезиальной изоляцией. М.: «Энергоатомиздат», 1984, с. 120.

6. Э.З. Аснович, В.А. Колганова. Высоконагревостойкая электрическая изоляция. М.: «Энергоатомиздат», 1988, с. 264.

7. С.В. Габелков, Р.В. Тарасов, Н.С. Полтавец. Эволюция фазового состава при термическом разложении гидроксида магния // Вопросы атомной науки и техники. 2011, №2(72), с. 72-75.

Статья поступила в редакциию 05.12.2019 2.

\title{
МИНЕРАЛЬНЫЕ ИЗОЛЯТОРЫ ДЛЯ КОМПТОНОВСКИХ ДЕТЕКТОРОВ НЕЙТРОНОВ С ЭМИТТЕРОМ ИЗ МЕТАЛЛИЧЕСКОГО ГАФНИЯ
}

\author{
Е.А. Богдан, Л.А. Пироженко, Р.В. Ажажа, С.В. Худяков, А.А. Веревкин, А.В. Рыбка, В.Е. Кутний, \\ К.В. Ковтун, С.А. Соколов, А.Л. Ульбкин, А.О. Пудов
}

Одна из наиболее приоритетных задач атомной энергетики - повышение надежности и безопасности ядерно-энергетических установок. В связи с этим совершенствуются и разрабатываются новые датчики измерения потока нейтронов в активной зоне реактора. Данная работа посвящена одному из этапов создания комптоновского детектора прямого заряда, а именно формированию изолятора из окиси магния на эмиттере из металлического гафния. Исследовано влияние трех видов оксида магния различной чистоты и структурного состояния, а также температуры отжига на электросопротивление изолятора между коллектором и эмиттером детектора. Изготовлены опытные образцы детекторов методами засыпки и нанесения жидкофазной смеси оксида магния.

\section{МІНЕРАЛЬНІ ІЗОЛЯТОРИ ДЛЯ КОМПТОНІВСЬКИХ ДЕТЕКТОРІВ НЕЙТРОНІВ 3 ЕМІТЕРОМ 3 МЕТАЛЕВОГО ГАФНІЮ}

\section{С.О. Богдан, Л.О. Піроженко, Р.В. Ажажса, С.В. Худяков, А.А. Верьовкін, О.В. Рибка, В.С. Кутній, К.В. Ковтун, С.О. Соколов, О.Л. Улибкін, О.О. Пудов}

Одним 3 пріоритетних завдань атомної енергетики є підвищення надійності та безпеки ядерноенергетичних блоків. 3 цією метою вдосконалюються та розробляються нові датчики для вимірювання потоку нейтронів в активній зоні реактора. Дана робота присвячена дослідженню магнію оксиду як ізолятора в комптоновських детекторах прямого заряду з емітером з металевого гафнію. Досліджено вплив трьох видів магнію оксиду різного за чистотою та структурою, а також температури відпалу на електроопір ізолятора між колектором та емітером детектора. Виготовлена ізоляція дослідженних зразків детектора щляхом насипу та нанесенням рідкофазної магнієвої суміші. 